\section{DEVELOPMENT OF LOCATION ESTIMATION ALGORITHM UTILIZING RSSI FOR LORA POSITIONING SYSTEM}

S. Kavetha, A. S. Ja'afar*, M. Z. A. Aziz, A. A. M. Isa, M. S. Johal, N. M. Z. Hashim

Center for Telecommunication Research \& Innovation (CeTRI), Faculty of Electronic and Computer Engineering (FKEKK), Univerisiti Teknikal Malaysia Melaka, Hang Tuah Jaya, 76100 Durian Tunggal, Melaka, Malaysia
Article history

Received

10 June 2021

Received in revised form

10 October 2021

Accepted

7 November 2021

Published Online

20 December 2021

*Corresponding author shukur@utem.edu.my

\section{Graphical abstract}

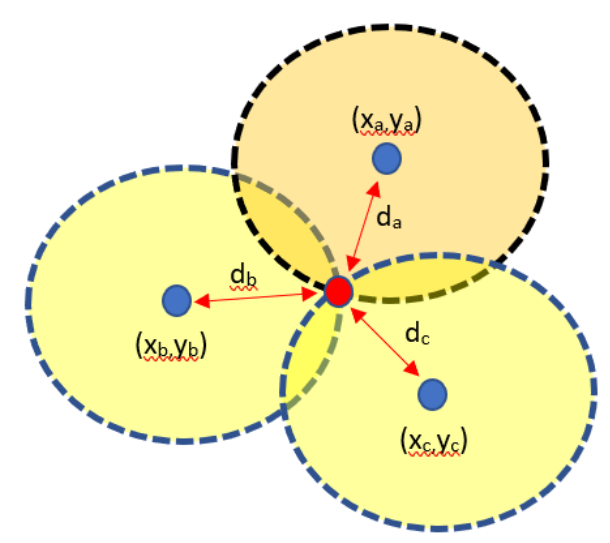

\begin{abstract}
LoRa is identified as Long-Range low power network technology for Low Power Wide Area Network (LPWAN) usage. Nowadays, Global Positioning System (GPS) is an important system which is used for location and navigation predominantly used in outdoor but less accurate in indoor environment. Most of LoRa technology have been used on the internet-of-things (ioT) but very few use it as localization system. In this project, a GPS-less solution is proposed where LoRa Positioning System was developed which consists of LoRa transmitter, LoRa transceiver and LoRa receiver. The system has been developed by collecting the RSSI which is then used for the distance estimation. Next, Kalman filter with certain model has been implemented to overcome the effect of multipath fading especially for indoor environment and the trilateration technique is applied to estimate the location of the user. Both distribution estimation results for Line-Of-Sight (LOS) and Non-Line-Of-Sight (NLOS) condition were analyzed. Then, the comparison RMSE achievement is analyzed between the trilateration and with the Kalman Filter. GPS position also were collected as comparison to the LoRa based positioning. Lastly, the Cumulative Density Function (CDF) shows $90 \%$ of the localization algorithm error for LOS is lower than 0.82 meters while for NLOS is 1.17 meters.
\end{abstract}

Keywords: Wireless Positioning, LoRa Positioning System, Trilateration, Indoor Positioning, Localization System

\begin{abstract}
Abstrak
LoRa dikenali sebagai teknologi rangkaian tenaga rendah jarak jauh untuk kegunaan Rangkaian Kawasan Luas Rendah Kuasa (LPWAN). Pada masa kini, Sistem Penentududukan Global (GPS) merupakan sistem penting yang digunakan untuk teknologi pengesanan lokasi dan navigasi yang kebanyakannya digunakan pada persekitaran luaran tetapi kurang tepat dalam kawasan tertutup. Kebanyakan teknologi LoRa digunakan pada internet kebendaan tetapi sangat jarang digunakan bagi tujuan penentududukan. Dalam projek ini, penyelesaian tanpa GPS dicadangkan di mana sistem penentududukan LoRa dibangunkan terdiri daripada pemancar LoRa, pemancar/penerima dan penerima LoRa. Sistem ini dibangunkan dengan mengumpul data RSSI yang kemudiannya digunakan dalam penentuan jarak. Seterusnya, penapis Kalman beserta model tertentu telah ditambahkan untuk mengatasi kesan pemudaran berbilang laluan terutama untuk persekitaran dalam bangunan dan teknik trilaterasi diterapkan untuk
\end{abstract}


menganggarkan lokasi pengguna. Taburan anggaran kedudukan bagi keadaan garis penglihatan (LOS) dan bukan garis penglihatan (NLOS) juga dianalisis. Kemudian, perbandingan pencapaian RMSE dianalisis antara trilaterasi dengan penapis Kalman. Data lokasi berasaskan GPS juga dikumpul sebagai perbandingan kepada sistem penentududukan LoRa. Akhirnya fungsi ketumpatan kumulatif (CDF) menunjukkan $90 \%$ ralat lokasi untuk LOS adalah rendah dari 0.82 meter manakala bagi NLOS adalah 1.17 meter.

Kata kunci: Penentududukan Tanpa Wayar, Penentududukan Sistem LoRa, Trilaterasi, Penentududukan Dalaman, Sistem Penyetempatan

(C) 2022 Penerbit UTM Press. All rights reserved

\subsection{INTRODUCTION}

Positioning system has been used in many sectors such as navigation, military, tracking devices, logistic and monitoring health care. Signal Based Positioning System has a lot of technologies such as Satellite Based Positioning, Cellular Network, Wi-Fi based Positioning System, Bluetooth Low Energy (BLE) and LoRa Positioning. GPS has been one of the outdoor positioning technologies used for outdoor conditions. GPS is recognized mostly as satellite navigation method for identifying the location of an object mostly on the ground. GPS receivers are included in several existing products such as automobiles, smartphones, exercise watches and Geographic Information System (GIS) devices.

For outdoor location, satellite-based positioning plays a significant role. Satellite positioning is the most popular due to the low cost compared to other navigation systems and it covers almost $100 \%$ of the Earth and is regularly updated [1]. Satellite-based positioning has been well known as the Global Navigation Satellite System (GNSS), the worldwide satellite-based radio navigation system consisting of 24 satellites evenly spaced in six orbital planes 20,200 kilometers away above the Earth, transmitting two specially designed carrier signals, one for civilian need and one for military and government need [2]. GNSS has several types of technologies which are Global Positioning System (GPS), Global Navigation Satellite System (GLONASS) and BeiDou Navigation Satellite System (BDS). The system's satellites send navigation signals used by a GPS receiver to identify its location however the satellite-based positioning system's signal could not reach much of the buildings' structure [3]. This makes it very difficult to establish location inside multi-story building, urban canyon and tunnel [4].

Due to weakness of GPS in indoor environment, Blvetooth and Wi-Fi are the most common technologies used for indoor positioning [5]. Wi-Fibased positioning is becoming a fascinating method because most mobile devices nowadays have their Wi-Fi modules such as smartphones and laptops [6]. Since the number of access point is rising it is becoming a fascinating device [7]. Blvetooth Low Energy (BLE) includes 40 2-MHz channels each BLE has a unique broadcast function without a master/slave connection for transmitting the message to the nearby peripheral[8]. Utilizing BLE tags in indoor positioning will create the link and calculate distances based on RSSI values and similarly display targeted BLE tag data. The mobile application enables users to estimate BLE tags that can get location evaluation based on parameters such as RSSI and transmission of power value [9].

LoRa is identified as Long-Range Low Power network technology which is categorized in LowPower Wide-Area Network (LPWAN), a non-cellular networking technology that facilitates long-range communication through low-power, low-cost loT devices and encourages machine-to-machine communication (M2M) network with allowing a longrange communication up to $10 \mathrm{~km}$. Regardless of its low bandwidth limit, LPWAN connectivity is therefore perfectly suggested for long-range wireless IOT applications. LoRa uses four types of frequencies worldwide which are $433 \mathrm{MHz}, 868 \mathrm{MHz}, 915 \mathrm{MHz}$ and $923 \mathrm{MHz}$. As approved by Malaysian Communications and Multimedia Commission (MCMC), the operating frequency for Malaysia is at $915 \mathrm{MHz}$ [10]. As LoRa is a revolutionary technology, there are only a few studies to comprehend LoRa technology's characterization and efficiency in positioning. Previous research on the outdoor positioning system studies different techniques such as Fingerprinting, Time of Arrival (ToA), TimeDifference of Arrival (TDOA) and Trilateration [11]. [12]. The main factor of trilateration is to measure the distance across Access Points (AP) and mobile devices to have a localization area. The distances can be estimated by distance estimation technique using RSSI measurement where the distance is firstly estimated by using a path LOSs model followed by location estimation using trilateration technique.

Besides loT (Internet of Things) applications in intelligent design and environmental networking, LoRa also offers an alternate way for outdoor localization. A few research has been carried out to show the suitability of using LoRa technologies as localization system [13]. Research conducted by Pengxin Guan et al. [14] to ease the people waiting for buses and make them more convenient to travel. In which the terminal system deployed on the bus 
transmits data to the data concentrators about its location. The data concentrators then upload information to the cloud and analyze it for users where the position of the bus is retrieved from GPS module [15].

Authors in [16] use basic trilateration utilizing the RSSI technique while implementing a path LOS model to approximate the distance as well as the position of both the user and the base station. The central idea of this trilateration process is that now the target node must be a circle centered from around anchor and a radius equal to the size of the node-anchor [17]. Another researcher by Aswin Tresna et al. used LoRa in medical sector to track mental disorder patient. In this study, GPS module was used to get the patient location and sent to LoRa gateway that is installed at the hospital and the system will notify the psychiatrist [18]. Besides location of the patient, the battery capacity and the RSSI data are also collected, and it was found the quicker the patient moves the higher the reduction in the battery capacity [19]. TDoA based positioning system was proposed by Nico Podevijin et al. based on TDoA on different scenarios such as walking, cycling, and driving. However, based on their study they only manage to get error more than 300 meters in $90 \%$ of the CDF [13]. You Li et al. suggested the use of LoRa's RSSI in wide area localization. Bayes framework was used in tracking the user in indoor and outdoor environment. Other factors such as signal coverage, signal distribution over space and time were also analyzed. The achievement of accuracy is $95 \%$ in 35 meters for outdoor and 34 meters for indoor. From the result, it needs a lot of study to be done to reduce the error of LoRa based positioning so that it can be used as an alternative to the well-known satellitebased positioning system [20].

This paper proposes GPS-less solution which is based on RSSI based positioning algorithm with advanced filtering technique to reduce the effect of multipath fading in LoRa positioning system. The project starts with hardware development on LoRa system, data collection, and then positioning algorithm development with certain model included. The rest of the paper is organized as follows; section 2 is about methodology, data collection, and algorithm design. Section 3 describes all the results and discussion including the error distribution analysis in different scenarios. Section 4 presents the conclusion and future works in this field.

\subsection{METHODOLOGY}

The positioning system based on the LoRa network utilizing the RSSI has been developed to estimate the location of the user. There are 4 major steps for this project before the user's location is estimated. First step is to set-up the LoRa positioning system which is the system development process where it consists of the LoRa transmitter, LoRa transceiver and LoRa receiver. The system consists of Node MCU ESP8266, Arduino UNO, LoRa module SX1278 (915 MHz) and GPS module (GY-NEO6MV2). In this work, for starting point, we start with small coverage area of $\sim 20 \mathrm{mx}$ $20 \mathrm{~m}$. Next, all the transmitters or also known as LoRa transmitters (LT) will transmit unique ID whereas the RSSI which is known as the Received Signal Strength Indicator is measured by the transceiver node and also receives the unique ID every 5 millisecond. The mobile LoRa transceiver is to collect the RSSI and the LoRa transmitter ID and transmits it to the fixed LoRa receiver where the RSSI and ID will be analyzed using MATLAB. Subsequently, the log-distance propagation model is used to estimate the distance and the Kalman filter is implemented to mitigate the distance error due to multipath fading. Next, the estimated distance is used in the trilateration algorithm, where each LoRa transmitter's position and the estimated distance are being calculated together to estimate the user position. The data sorting, filtering and the location estimation are designed using MATLAB. Figure 1 shows the overall LoRa positioning system set-up which consists of 3 LoRa transmitters (LT), 1 mobile LoRa transceiver and 1 LoRa receiver. Table 1 shows the parameters that are used in the LoRa Positioning system.

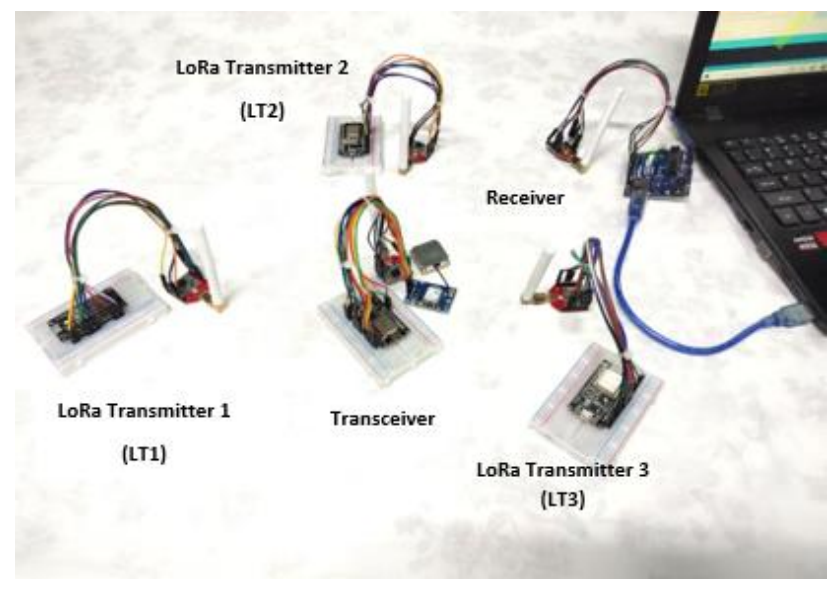

Figure 1 LoRa Positioning System Set-Up

Table 1 Parameters of LoRa Positioning System

\begin{tabular}{cccc}
\hline $\begin{array}{c}\text { LoRa } \\
\text { Transmitters }\end{array}$ & ID & $\begin{array}{c}\text { Frequency } \\
\text { band }\end{array}$ & $\begin{array}{c}\text { RSSI } \\
\text { (-dBm) }\end{array}$ \\
\hline LT1 & LT1xly1 & $915 \mathrm{MHz}$ & $88-91$ \\
LT2 & LT2x2y2 & $915 \mathrm{MHz}$ & $89-91$ \\
LT3 & LT3x3y3 & $915 \mathrm{MHz}$ & $89-90$ \\
\hline
\end{tabular}

Figure 2 shows the flowchart of the overall LoRa positioning system. The RSSI was collected for the purpose of designing positioning algorithm while the GPS location was collected for comparison. Phase 1 is the system development and data collection. Next, in phase 2 is the algorithm development meanwhile phase 3 is the analysis of position estimation algorithm. 


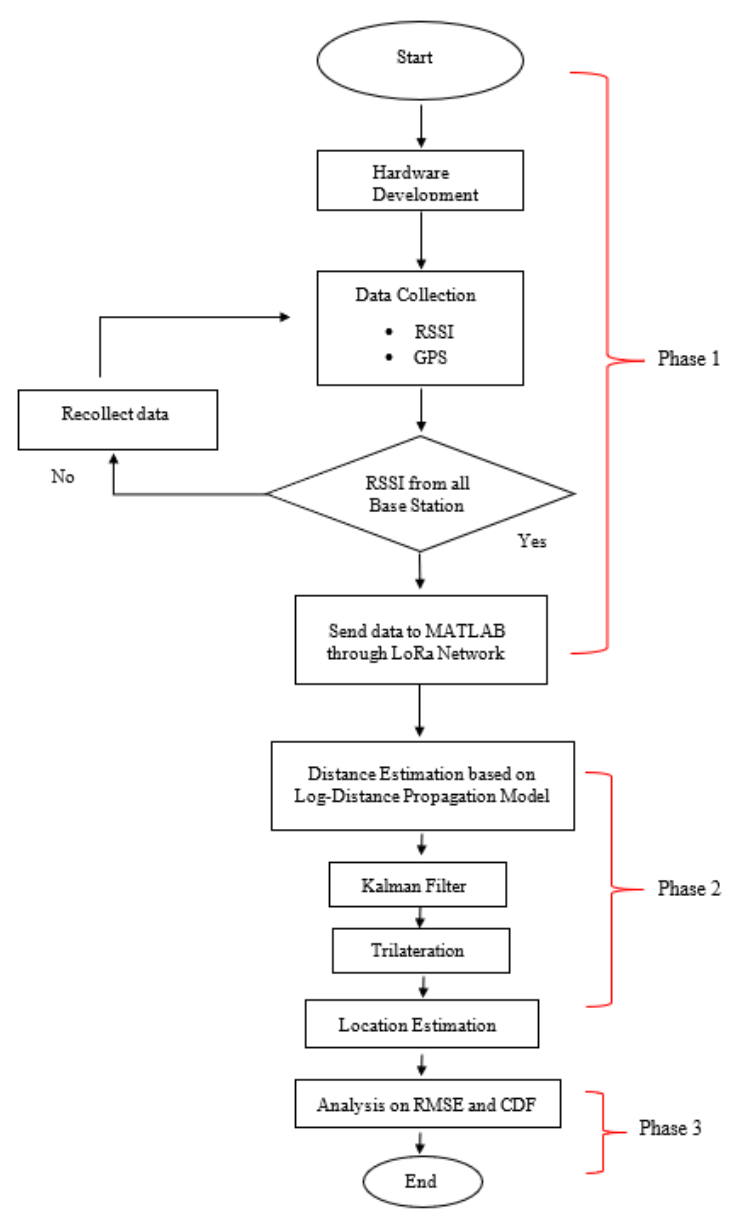

Figure 2 Flowchart of the LoRa Positioning System

\subsection{Data Collection}

The LoRa trasnmitters are placed at three different positions in Line-Of-Sight (LOS) and Non-Line-Of-Sight (NLOS) conditions as shown in Figure 3 and Figure 4. The red dots represent the LoRa transmitters (LT) which are in a form of a triangle with radius of $10 \mathrm{~m}$ and the yellow dot represents the target node. Each of the transmitter is labelled as LT1, LT2 and LT3, respectively. The transmitters transmit the unique ID data to the transceiver node and at the same time GPS data are retrieved at the transceiver node itself. Here the RSSI level are measured by the transceiver.

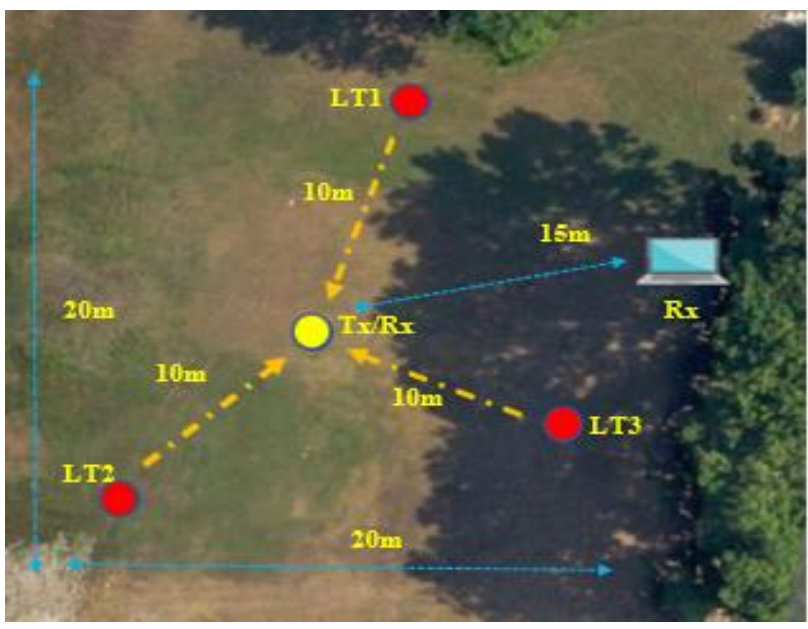

Figure 3 LOS condition

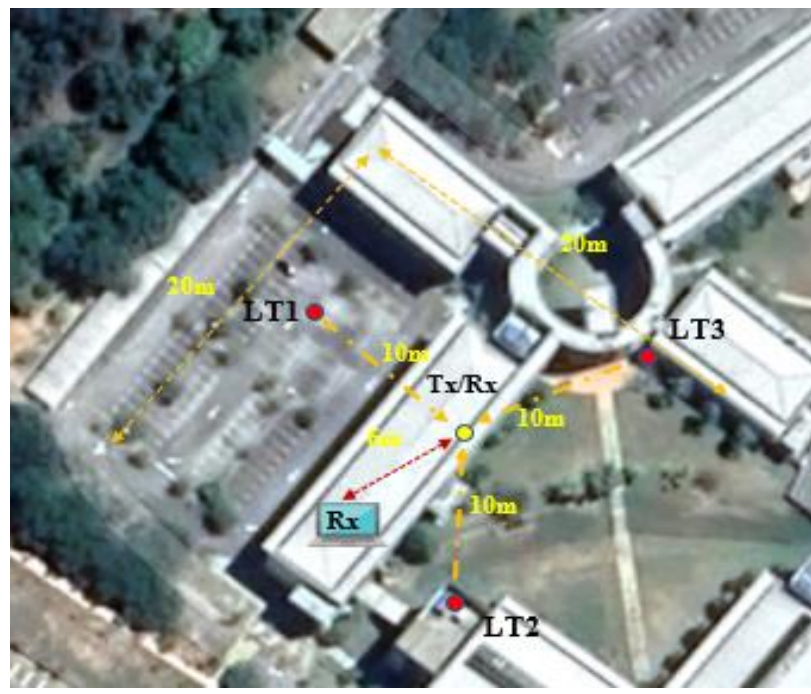

Figure 4 NLOS condition

\subsection{Distance Estimation}

The RSSI level are analyzed using the MATLAB software. Distance estimation is done by a propagation model which is by using a log-distance path Loss model as shown below [21],

$$
R S S I=10 n \log _{10} d+A
$$

Where: $n=$ path LOSs exponent, $d=$ distance from the transmitter, $A=$ reference value of RSSI at 1 meter away.

The equation is then rearranged to make the $d$ as the subject as the $d$ is the one that has to be found. The path LOSs exponent value differs according to the environment that is used for the experiment. In this project, for LOS $n=2.0$ as it is an open space and for the NLOS $n=2.7$ as it is in urban environment.

$$
d=10^{\left(\frac{R S S I-A}{10 n}\right)}
$$




\subsection{Kalman Filter}

Kalman filter includes multiple iterative methods, such as with state and error covariance prediction, measurement updates with Kalman gain and an estimation as the output. Finally, error covariance calculation that show how rough approximations are then update as new input to the iteration. The Kalman filter structure has one measurement input $Z_{k}$ and one estimation output $\hat{X}_{k}$ as shown in Figure 5 . There are four system models $A, H, Q$, and $R$. $A$ is the state transition matrix, $H$ is the state to measurement matrix, $Q$ is the covariance matrix of transition noise, and $R$ is the covariance matrix of measurement noise. This filter is used after the distance estimation to overcome and compensate the effect of signal fluctuation due to reflection, refraction and propagation to receiver [22].

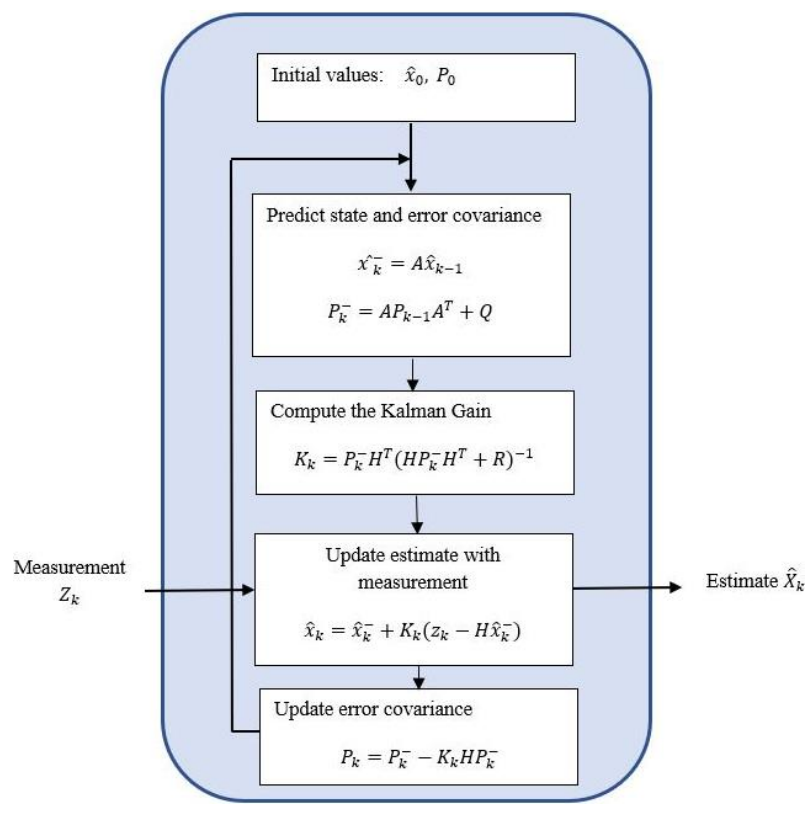

Figure 5 General algorithm of Kalman Filter

Below shows the system model that is used in the Kalman Filter,

$$
\begin{aligned}
& X_{k}=\left\{\frac{\text { Position }}{\text { Velocity }}\right\} \\
& X_{k}=A=X_{k-1} \\
& \left\{\frac{\text { Position }}{\text { Velocity }}\right\}=\left[\begin{array}{cc}
1 & \Delta t \\
0 & 1
\end{array}\right]\left[\begin{array}{l}
\text { Position } \\
\text { Velocity }
\end{array}\right]_{k-1}
\end{aligned}
$$

\subsection{Trilateration}

After retrieving the new estimated distance, it is used to estimate the location by using the trilateration method where the position of the base stations must be known [23], [24]. It is assumed that all the nodes span out to the same plane which considers the three transmitter nodes to be $S_{1}, S_{2}$ and $S_{3}$ which has the distance of $d_{1}, d_{2}$ and $d_{3}$ to the target node as shown in the Figure 6 below.

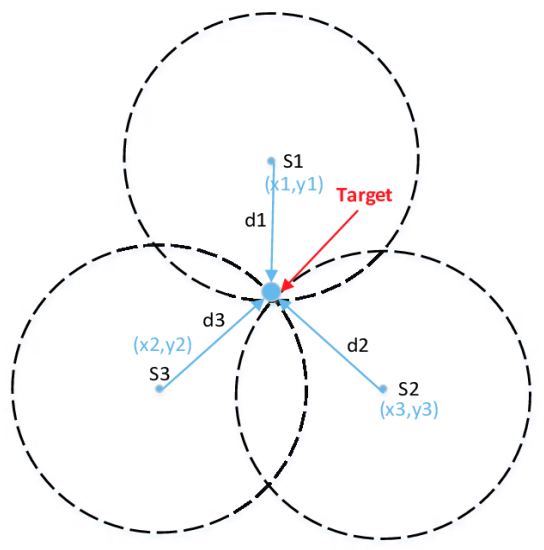

Figure 6 Trilateration Technique

The formula for all the circles in one plane is shown below:

$$
\begin{array}{ll}
\text { Circle A: } d_{1}{ }^{2}=\left(x-x_{1}\right)^{2}+\left(y-y_{1}\right)^{2} & -(6.0) \\
\text { Circle B: } d_{2}{ }^{2}=\left(x-x_{2}\right)^{2}+\left(y-y_{2}\right)^{2} & -(7.0) \\
\text { Circle C: } d_{3}{ }^{2}=\left(x-x_{3}\right)^{2}+\left(y-y_{3}\right)^{2} & -(8.0)
\end{array}
$$

The equation above can be expanded further as shown below:

$$
\begin{array}{cc}
d_{1}{ }^{2}=x^{2}-2 x \cdot x_{1}+x_{1}{ }^{2}+y^{2}-2 y \cdot y_{1}+y_{1}{ }^{2} & -(9.0) \\
d_{2}{ }^{2}=x^{2}-2 x \cdot x_{2}+x_{2}{ }^{2}+y^{2}-2 y \cdot y_{2}+y_{2}{ }^{2} & -(10.0) \\
d_{3}{ }^{2}=x^{2}-2 x \cdot x_{3}+x_{3}{ }^{2}+y^{2}-2 y \cdot y_{3}+y_{3}{ }^{2} & -(11.0)
\end{array}
$$

Equation (9.0), (10.0) and (11.0) are independent non-linear simultaneous equations that could not be solved but to obtain radical plane for a circle intersection, the equations can be subtracted. The following linear equation can be obtained by subtracting Equation (11.0) from Equation (10.0) and rearrange it:

$$
\begin{aligned}
& x\left(x_{3}-x_{2}\right)+y\left(y_{3}-y_{2}\right)=\frac{\left(d_{2}{ }^{2}-d_{\mathrm{a}}{ }^{2}\right)-\left(x_{\mathrm{z}}{ }^{2}-x_{\mathrm{a}}{ }^{2}\right)-\left(y_{\mathrm{z}}{ }^{2}-y_{\mathrm{a}}{ }^{2}\right)}{2}= \\
& v_{a}
\end{aligned}
$$

Subtracting equation (7.0) from equation (6.0) and rearrange it will form another new equation:

$$
\begin{aligned}
& x\left(x_{1}-x_{2}\right)+y\left(y_{1}-y_{2}\right)=\frac{\left(d_{2}^{2}-d_{1}^{2}\right)-\left(x_{2}^{2}-x_{1}^{2}\right)-\left(y_{2}^{2}-y_{1}^{2}\right)}{2}= \\
& v_{b}
\end{aligned}
$$

By solving Equation (12.0) and (13.0), we can get the intersection points ' $x$ ' and ' $y$ ' of these two equations as shown in the following equations for ' $y$ ' and ' $x$ ' values respectively: 


$$
\begin{array}{ll}
y=\frac{v_{b}\left(x_{3}-x_{2}\right)-v_{a}\left(x_{1}-x_{2}\right)}{\left(y_{1}-y_{2}\right)\left(x_{2}-x_{2}\right)-\left(y_{2}-y_{2}\right)\left(x_{1}-x_{2}\right)} & -(14.0) \\
x=\frac{v_{a}-y\left(y_{3}-y_{2}\right)}{\left(x_{2}-x_{2}\right)} & -(15.0)
\end{array}
$$

The values of $x$ and $y$ gives the estimated position for the target node. As there are 50 RSSI collected data in each cycle therefore the return values will be 50x's and 50y's. All the estimation location points are then used in the analysis of error location using the Root Mean Square Error (RMSE) and Cumulative Density Function (CDF).

\subsection{RESULTS AND DISCUSSION}

\subsection{RSSI And Distance Estimation}

When measuring the RSSI level, the data are in heavy fluctuation form as shown in Figure 7. From LoRa transmitter 1, 2 and 3, the difference of fluctuation RSSI is up to $4 \mathrm{dBm}$ level. The reason for the fluctuation is the effect of the multipath fading of signal transmission. The RSSI is used in the log-distance propagation model to estimate the distance. Subsequently, the Kalman Filter is applied to mitigate the multipath fading, and the distance is estimated again. Both estimated distance with and without the Kalman Filter have been analyzed. Figure 8 depicts the comparison of distance estimation graph with and without the Kalman Filter. The blue line is the distance estimation without the Kalman Filter whereas the red line is the distance estimation with Kalman filter.
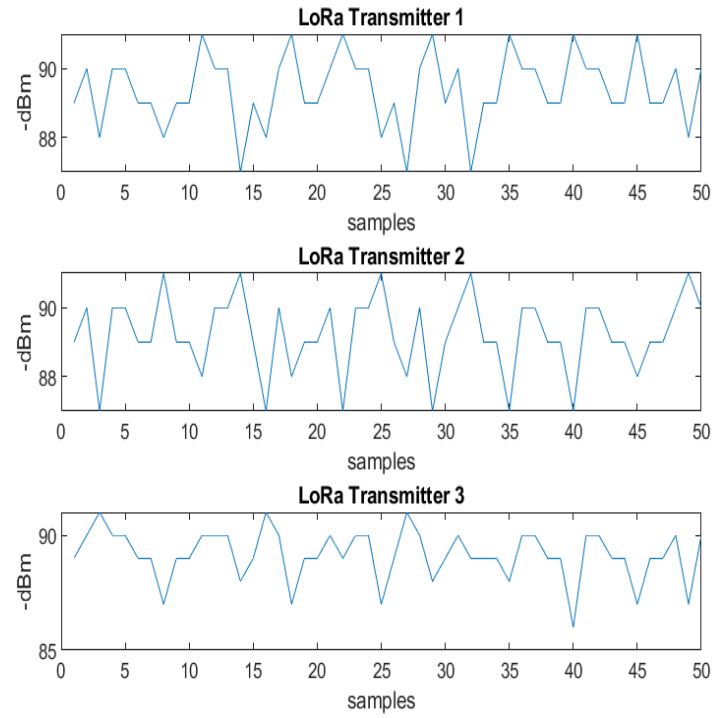

Figure 7 RSSI Fluctuation
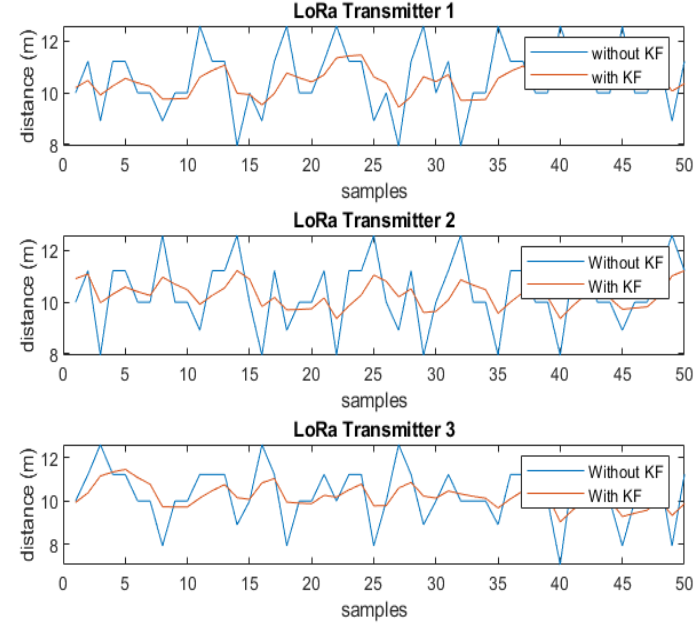

Figure $\mathbf{8}$ Distance Estimation with and without Kalman Filter

3.2 Trilateration for with and without Kalman Filter for Fixed Position and Movement

Figure 9 shows the trilateration for the LOS condition of 10 meters of a fixed position. The black cross point represents the actual position of the user, the blue dots represent the estimated location of the user without the Kalman Filter and the red dots represents the estimated location with the Kalman Filter. This measurement and analysis have been done with 50 data samples. With the Kalman Filter, it shows a more accurate location near to the actual point compares to those without the filter.

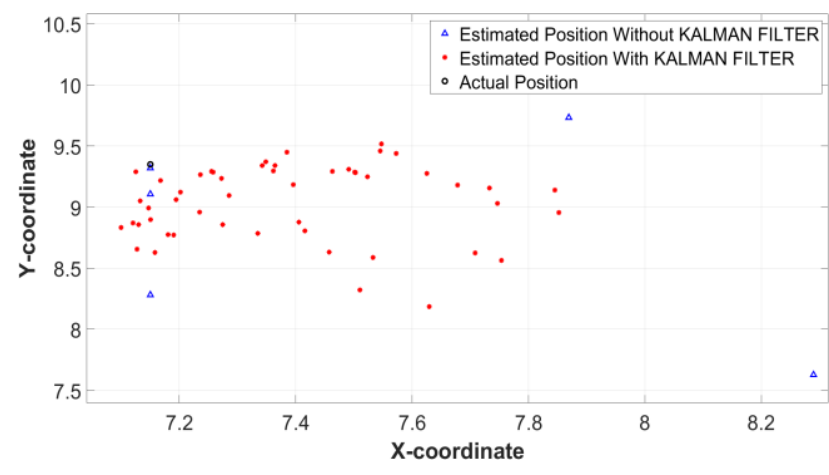

Figure 9 Trilateration LOS for Fixed Position

Next, the RMSE of the location position is being calculated using Equation 16.0 below.

$$
R M S E=\sqrt{\sum_{i=1}^{n} \frac{\left(x_{\text {actual }}-x_{\text {estimated (i) }}\right)^{2}+\left(\text { Yactual }-y_{\text {estimated }(\mathrm{i})}\right)^{2}}{N}}
$$


Where Xactual and yactual is the actual position of the user, Xestimated(i) and Yestimated(i) is the estimated location of the user, and $N$ is the total number of sampled data. Figure 10 below depicts the trilateration for NLOS condition of 10 meters of a fixed position whereas Figure 11 and Figure 12 shows the trilateration for LOS and NLOS for movement respectively.

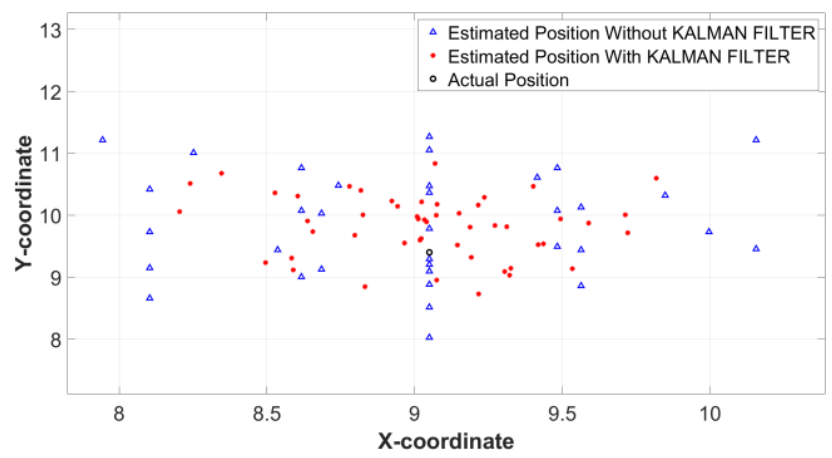

Figure 10 Trilateration NLOS for Fixed Position

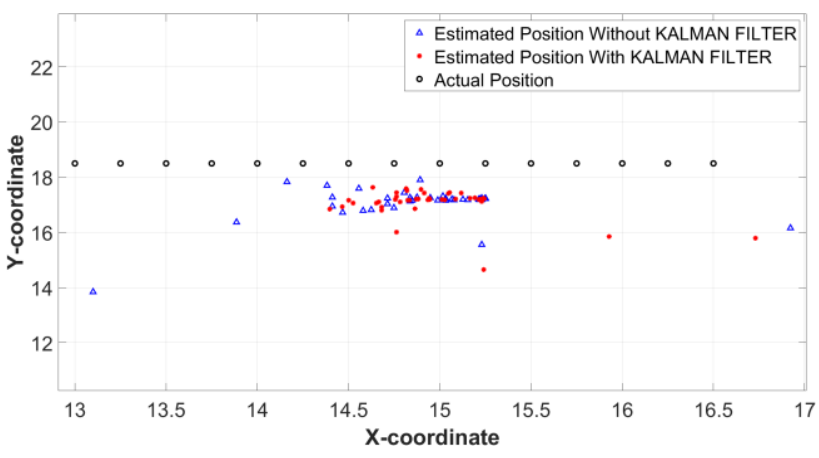

Figure 11 Trilateration LOS for Movement

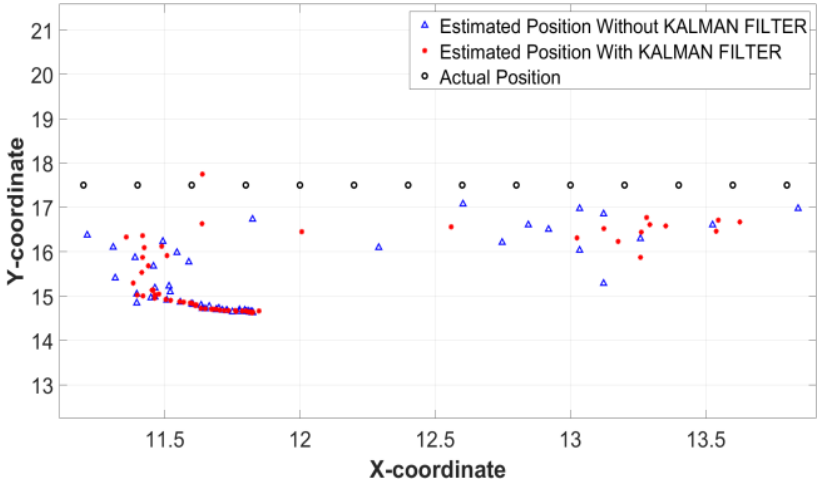

Figure 12 Trilateration NLOS for Movement

Table 2 shows the error of the positioning using the filter for LoRa Positioning for both LOS and NLOS condition for fixed positions and movement condition. In conclusion for both LOS and NLOS conditions, using the Kalman Filter improve the accuracy of the estimated position near to the actual position compared to the estimated points that are retrieved without the Kalman Filter.
Table 2 RMSE Error for all conditions with Kalman Filter

\begin{tabular}{lll}
\hline \multicolumn{1}{c}{ Scenario } & Fixed Positions & Movement \\
\hline LINE-OF-SIGHT (LOS) & 0.539147409 & 1.299434922 \\
NON-LINE-OF-SIGHT & 0.752739542 & 2.931060659 \\
(NLOS) & \\
\hline
\end{tabular}

Figure 13 depicts the location error distribution in boxplot form for four scenario conditions which are fixed position for LOS, NLOS, mobile positions for LOS and NLOS. Fixed position LOS shows the least error in location among these four scenarios with median -0.4 meters and positively skewed distribution. Clearly, there are some outliers located outside the whiskers up to 1.8 meters in error locations. In fixed NLOS condition, it shows the same positively skewed distribution with larger interquartile range and whiskers range compared to LOS scenario. In mobile LOS condition, it shows larger error distribution with long whiskers on positive skewed. Lastly, mobility with NLOS condition gives the largest error distribution and median $\sim 7.5$ meters. The error distribution is negatively skewed with the range of interquartile and whisker larger compared to that of the fixed position NLOS. These indicate the location error is dispersed and scattered more widely as compared to other scenarios. Among the reason why mobility condition giving dispersed error location is due to the algorithm that have been designed does not include the tracking capabilities.

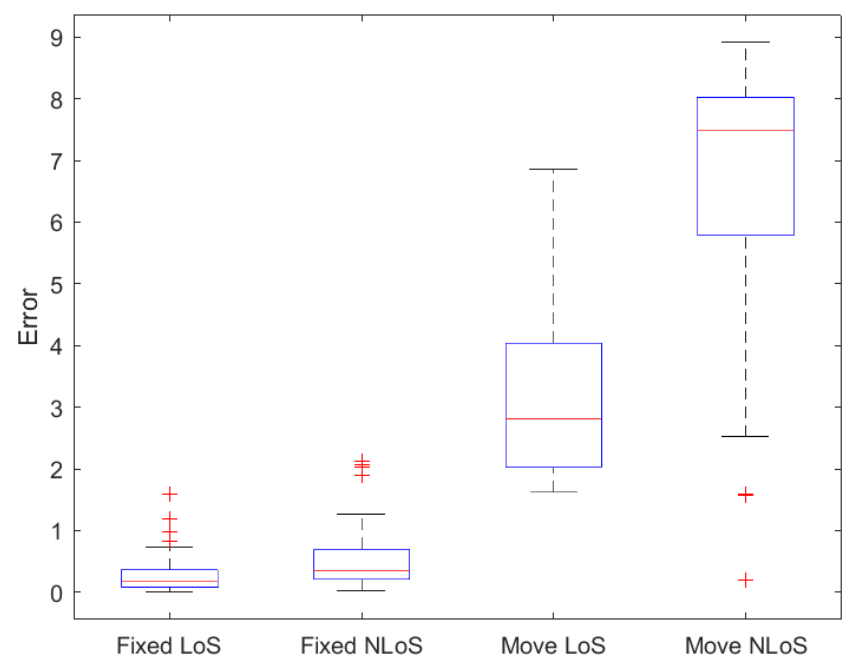

Figure 13 Boxplot distribution of location error in fix location LOS, NLOS, movement LOS and NLOS

\subsection{LoRa Positioning and GPS}

This part shows the analysis of LoRa estimated positioning error compared to GPS error. Figure 14 depicts the average of estimated LoRa position compared to actual and GPS position in LOS condition. Meanwhile, Figure 15 portrays the results of 
average estimated position in NLOS condition. The black dot represents the GPS position, the red square represents the actual position and the green diamond shape indicate the estimated position. The estimated position shown is the average position of the 50-sample RSSI.

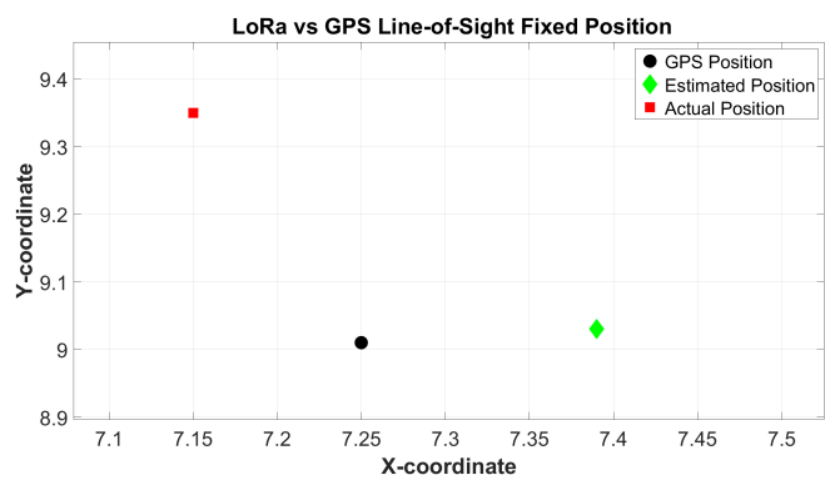

Figure 14 Average LoRa Positioning and GPS Fixed Position (LOS)

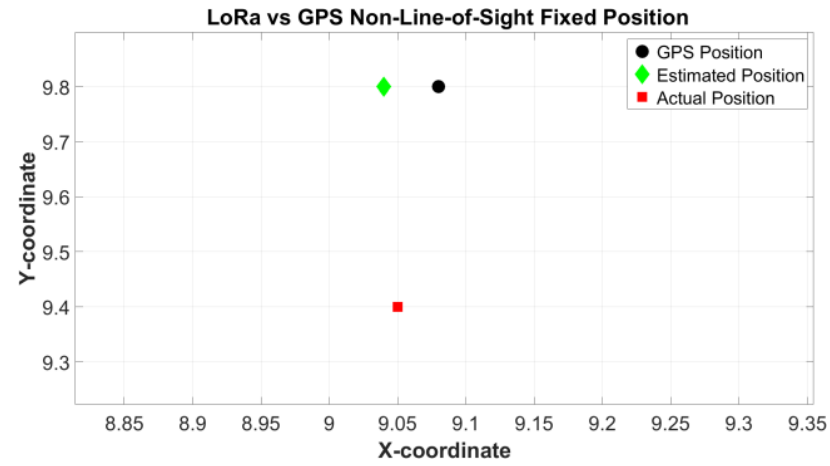

Figure 15 Average LoRa Positioning and GPS Fixed Position (NLOS)

Table 3 depicts the RMSE positioning error for both LORa Positioning System and the GPS in LOS and NLOS environment. It can be said that for LOS condition, GPS give the least error in positioning (0.3544009) whereas in NLOS condition LoRa based Positioning system give better accuracy. In LOS scenario, GPS signal can be retrieved but in case of NLOS scenario, the GPS signal is partially blocked and that is the reason it has greater error of positioning. In worse case condition, the GPS signal is totally blocked and didn't return any user location. This is where LoRa based Positioning System have a distinct advantage over other systems.

Table 3 Comparison of RMSE Error for LoRa Positioning and GPS

\begin{tabular}{llc}
\hline SCENARIOS & $\begin{array}{l}\text { LINE-OF-SIGHT } \\
\text { (LOS) } \\
\text { FIXED POSITION }\end{array}$ & $\begin{array}{l}\text { NON-LINE-OF-SIGHT } \\
\text { (NLOS) } \\
\text { FIXED POSITION }\end{array}$ \\
\hline $\begin{array}{l}\text { LORA POSITIONING } \\
\text { ERROR } \\
\text { GPS ERROR }\end{array}$ & 0.53914741 & 0.752739542 \\
\hline
\end{tabular}

\subsection{CDF}

Figure 16 shows the CDF of fixed position for LoRa Positioning System, it can be said that $90 \%$ of the estimated location with the Kalman Filter has the error for 0.82 meters for LOS condition whereas for the NLOS condition it has error for 1.17 meters.

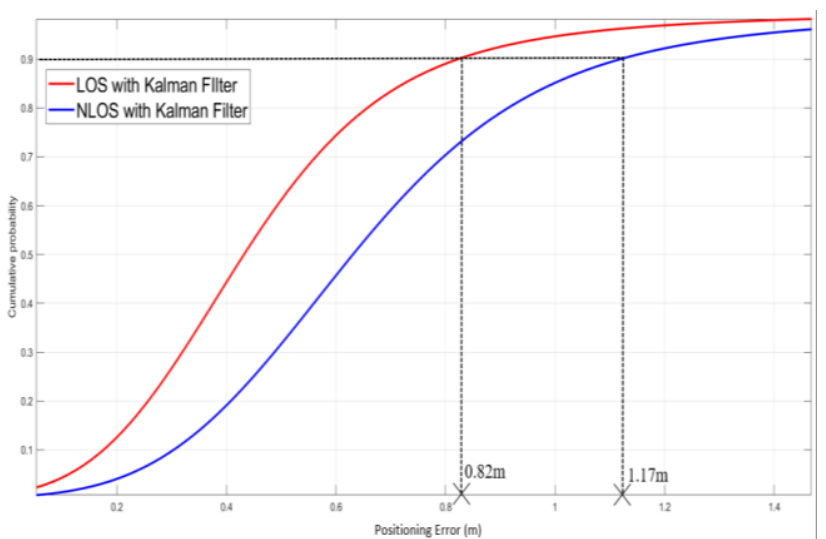

Figure 16 CDF error position for Fixed Position of Both LOS and NLOS

\subsection{CONCLUSION}

The localization system based on the LoRa network has been designed successfully with the LoRa Transmitter, LoRa Transceiver and LoRa Receiver. LoRa based location estimation algorithm has been successfully developed based on the log-distance propagation model and the Kalman filter utilizing the RSSI to overcome the multipath fading. The propagation model and the filter were used to estimate a stabilize distance and it was used in the trilateration algorithm to obtain the estimated location. From the results, the estimated location's error was nearly the same as the GPS error. For the CDF at fixed position, $90 \%$ of error of the sample data for LOS is 0.82 meters and for NLOS is 1.17 meters.

For Lora Positioning, LOS condition gives a better accuracy compared to the NLOS condition. Using Kalman Filter in the distance and location estimation produces more accurate and stable result compared to result without Kalman Filter. For this project, it shows that LoRa Positioning is better in NLOS condition and GPS is better in LOS condition. It can be concluded that if the GPS is blocked in the NLOS environment, the alternative solution to track or locate a user or and an asset is by using LoRa Positioning System.

\section{Acknowledgement}

The authors would like to thank the Universiti Teknikal Malaysia Melaka (UTeM), UTeM Zamalah Scheme for sponsoring this research. 


\section{References}

[1] Henriksson, R. 2016. Indoor Positioning in LoRaWAN Networks: Evaluation of RSS Positioning in LORaWAN Networks using Commercially Available Hardware. Master's Thesis. Chalmers University of Technology. 38.

[2] Oderwald, R. G., \& Boucher, B. A. 2003. GPS after Selective Availability: How Accurate is Accurate Enough? Journal of Forestry. 101(4): 24-28. https://doi.org/10.1093/jof/101.4.24.

[3] Caffery, J. J. 2000. New Approach to the Geometry of TOA Location. IEEE Vehicular Technology Conference. $4(52$ ND): 1943-1949. https://doi.org/10.1109/vetecf.2000.886153

[4] Widyawan, Klepal, M., \& Pesch, D. 2007. Influence of Predicted and Measured Fingerprint on the Accuracy of RSSI-based Indoor Location Systems. 4th Workshop on Positioning, Navigation and Communication 2007. WPNC'07 - Workshop Proceedings, 2007. 145-151. https://doi.org/10.1109/wpnc.2007.353626.

[5] Library, P. Y., Hom, H., \& Kong, H. (n.d.). RSSI-BASED LOCALIZATION The Hong Kong Polytechnic University.

[6] Shekhar, S., \& Xiong, H. 2008. Indoor Positioning System. Encyclopedia of GIS. 566-566. https://doi.org/10.1007/9780-387-35973-1_628.

[7] Shchekotov, M. 2014. Indoor Localization Method Based on Wi-Fi Trilateration Technique. Proceeding of the 16Th Conference of Fruct Association. 177-179. https://fruct.org/publications/abstract16/files/Shcl.pdf

[8] Lam, K. H., Cheung, C. C., \& Lee, W. C. 2017. LoRa-based Localization Systems for Noisy Outdoor Environment. International Conference on Wireless and Mobile Computing, Networking and Communications, 2017Octob. 278-284. https://doi.org/10.1109/WiMOB.2017.8115843.

[9] Zeimpekis, V., Giaglis, G. M., \& Lekakos, G. 2002. A Taxonomy of Indoor and Outdoor Positioning Techniques for Mobile Location Services. ACM SIGecom Exchanges. 3(4): 19-27. https://doi.org/10.1145/844351.844355.

[10] Lam, K. H., Cheung, C. C., \& Lee, W. C. 2019. RSSI-based LoRa Localization Systems for Large-scale Indoor and Outdoor Environments. IEEE Transactions on Vehicular Technology. 68(12): 11778-11791. https://doi.org/10.1109/TVT.2019.2940272.

[11] Podevijn, N., Plets, D., Trogh, J., Martens, L., Suanet, P., Hendrikse, K., \& Joseph, W. 2011). TDoA-based Outdoor Positioning with Tracking Algorithm in a Public LoRa Network. Wireless Communications and Mobile Computing, 2018. https://doi.org/10.1155/2018/1864209.

[12] Choi, W., Chang, Y., Jung, Y., \& Song, J. 2018. Low-Power LoRa Signal-Based Outdoor Positioning Using Fingerprint Algorithm. 1-15. https://doi.org/10.3390/ijgi71 10440

[13] Plets, D., Podevijn, N., Trogh, J., Martens, L., \& Joseph, W.
201). Experimental Performance Evaluation of Outdoor TDOA and RSS Positioning in a Public LoRa Network. IPIN 2018 - 9th International Conference on Indoor Positioning and Indoor Navigation, September. 1-8. https://doi.org/10.1109/IPIN.2018.8533761.

[14] Guan, P. 2018. A Real-time Bus Positioning System Based on LoRa Technology. 2018 2nd International Conference on Smart Grid and Smart Cities (ICSGSC). 45-48.

[15] Kim, D. H., Lim, J. Y., \& Kim, J. D. 2016. Low-power, Longrange, High-data Transmission using Wi-Fi and LoRa. 2016 6th International Conference on IT Convergence and Security, ICITCS 2016. https://doi.org/10.1109/ICITCS.2016.7740351.

[16] Daiya, V., Ebenezer, J., Murty, S. A. V. S., \& Raj, B. 2011. Experimental Analysis of RSSI for Distance and Position Estimation. International Conference on Recent Trends in Information Technology, ICRTIT 2011. 1093-1098. https://doi.org/10.1109/ICRTIT.2011.5972367.

[17] Raju, V. 2017 An Environmental Pollution Monitoring System u sing LORA. 2017 International Conference on Energy, Communication, Data Analytics and Soft Computing (ICECDS). 3521-3526.

[18] Hayati, N., \& Suryanegara, M. 2017. The loT LoRa System Design for Tracking and Monitoring Patient with Mental Disorder. 2017 IEEE International Conference on Communication, Networks and Satellite, COMNETSAT 2017 Proceedings, 2018-Janua 135-139. https://doi.org/10.1109/COMNETSAT.2017.8263587.

[19] Nugraha, A. T. 2018. An loT-LoRa System for Tracking a Patient with a Mental Disorder: Correlation between Battery Capacity and Speed of Movement. 2018 7th International Conference on Computer and Communication Engineering (ICCCE). 198-201.

[20] Li, Y., Yan, K., He, Z., Li, Y., Gao, Z., Pei, L., Chen, R., \& ElSheimy, N. 2019. Cost-effective Localization using RSS from Single Wireless Access Point. IEEE Transactions on Instrumentation and Measurement. 69(5): 1860-1870.

[21] Razali, N. A. M., Habaebi, M. H., Zulkurnain, N. F., Islam, M. R., \& Zyoud, A. 2017. The Distribution of Path Loss Exponent in 3D Indoor Environment. International Journal of Applied Engineering Research. 12(18): 7154-7161.

[22] Li, X., Wang, K., Wang, W., \& Li, Y. 2010. A Multiple Object Tracking Method Using Kalman Filter. 2010 IEEE International Conference on Information and Automation, ICIA $2010 . \quad 1862-1866$. https://doi.org/10.1109/ICINFA.2010.5512258

[23] Zhang, A., Ye, X., \& Hu, H. 2012. Point in Triangle Testing based Trilateration Localization Algorithm in Wireless Sensor Networks. KSII Transactions on Internet and Information Systems. 6(10): 2567-2586. https://doi.org/10.3837/tiis.2012.10.007.

[24] Poellabave, Waltenegus, D. and C. 2010. Chapter 10: Localization Chapter 10: Roadmap. 